\title{
E-SAFETY: KEAMANAN DI DUNIA MAYA BAGI PENDIDIK DAN ANAK DIDIK
}

\author{
Niyu ${ }^{1}$, Herman Purba ${ }^{2}$ \\ ${ }^{1,2}$ Universitas Pelita Harapan
}

Niyu.fisip@uph.edu , herman.purba@uph.edu

\begin{abstract}
Abstrak
Berdasarkan data Child Online Safety Index (COSI), Indonesia menempati posisi terendah untuk bimbingan dan edukasi terkait keamanan online. Kondisi ini menempatkan anak-anak dan remaja pada posisi yang sangat rentan ketika berinteraksi di dunia digital. Dengan beralihnya proses pembelajaran ke platform online pada masa pandemi COVID-19 pada tahun 2020, kami melihat bahwa pembekalan akan fungsi dan keamanan di dunia maya (E-Safety) menjadi semakin krusial untuk menjaga anak didik ketika berinteraksi di dunia digital. PkM ini dilaksanakan sebagai salah satu upaya untuk meningkatkan kesadaran dan memperlengkapi para pendidik dalam literasi digital terkait edukasi E-Safety. Implementasi E-Safety ini sejalan dengan program pemerintah dalam mendukung Gerakan Nasional Literasi Digital (GNLD). Pelaksanaan PkM dilakukan dalam bentuk webinar dan workshop. Terdapat 57 peserta pendidik dari berbagai yayasan pendidikan, guru-guru TK-SMA, PGRI, dan aktivis gereja sebagai peserta. Sosialisasi mengenai E-Safety bagi pendidik juga disertai dengan memberikan berbagai sumber referensi yang dapat digunakan untuk pembuatan bahan ajar E-Safety. Penekanan akan peranan pendidik sebagai Learner, Advisor, Teacher, dan An Identifier menjadi kunci utama dalam meningkatkan resiliensi anak didik untuk menghadapi situasi serta permasalahan ketika berinteraksi di dunia digital. Hasil dari kegiatan ini adalah pemahaman akan pentingnya E-Safety serta implementasi penggunaan bahan ajar E-Safety dalam mendukung resiliensi anak didik ketika berinteraksi di dunia digital.
\end{abstract}

Kata Kunci : E-Safety, literasi digital, online learning, internet aman, pendidik

\section{PENDAHULUAN}

Dunia pendidikan tidak dapat terhindar dari dampak Pandemi Covid-19 yang terjadi di Indonesia sejak bulan Maret 2020. Surat Edaran Nomor 4 Tahun 2020 tentang Pelaksanaan Kebijakan Pendidikan Dalam Masa Darurat Penyebaran Coronavirus Disesase (Covid-19) menjelaskan bahwa kegiatan belajar-mengajar akan dilaksanakan secara daring (dalam jaringan) dengan menerapkan sistem Pembelajaran Jarak Jauh (PJJ) yang dilaksanakan dari rumah masing-masing (Dewi, W: 2020).
Kegiatan belajar-mengajar secara daring harus dilakukan dengan tetap memperhatikan faktor keamanan selama beinteraksi di dunia maya sehingga pembelajaran dan eksplorasi yang dilakukan dapat maksimal dan kondusif. Zilka (2017) menjelaskan bahwa isu utama yang berkaitan dengan berbagai aktivitas online adalah keamanan, termasuk mengenai privasi online, cyberbullying, paparan konten-konten kekerasan, pengucilan, kebencian, berkomunikasi dengan orang yang sama sekali tidak dikenal serta 
penggunaan bahasa yang tidak sepatutnya diucapkan.

Keresahan yang dialami oleh guru dan staff dalam menghadapi pola baru pada dunia pendidikan dengan sistem pembelajaran daring juga terlihat dari hasil evaluasi yang kami lakukan pada kegiatan Pengabdian Kepada Masyarakat sebelumnya (Literasi Digital 1.0) yang berlangsung pada bulan Mei 2020. Para peserta yang merupakan tenaga pendidik masih belum memiliki pengalaman yang cukup untuk melaksanakan kegiatan belajarmengajar secara daring.

Sudrajat (2020) menyatakan bahwa keterampilan dibidang Ilmu Pengetahuan dan Teknologi (IPTEK) dapat mempengaruhi proses pembimbingan siswa jarak jauh serta sangat dibutuhkan untuk pelaksanaan kegiatan belajar mengajar secara daring yang diterapkan oleh sekolah. Zhu \& Liu (2020) juga berpendapat bahwa guru diharapkan memiliki pengetahuan, keterampilan, dan etika untuk melakukan pengajaran secara daring, sehingga lebih fleksibel dan dinamis guna menyediakan pendidikan secara jarak jauh yang berkualitas tinggi.

Berkembangnya ICT (Information Communication Technology) dengan pesat, memberikan kesempatan yang semakin luas untuk setiap orang memiliki akses dan telah menjadi solusi dikala pembelajaran berpindah menjadi online. Pada saat yang bersamaan, akses ke dunia maya menjadi semakin intens ketika harus digunakana sebagai persayaratan dalam menjalankan proses belajar mengajar secara online. Di sisi lain kurangnya literasi digital terkait berbagai resiko dan bahaya yang mungkin dihadapi juga menjadi terbuka lebar dan dapat menjadi ancaman bagi penggunanya. Mereka yang paling rentan dalam hal ini adalah anak dan remaja.

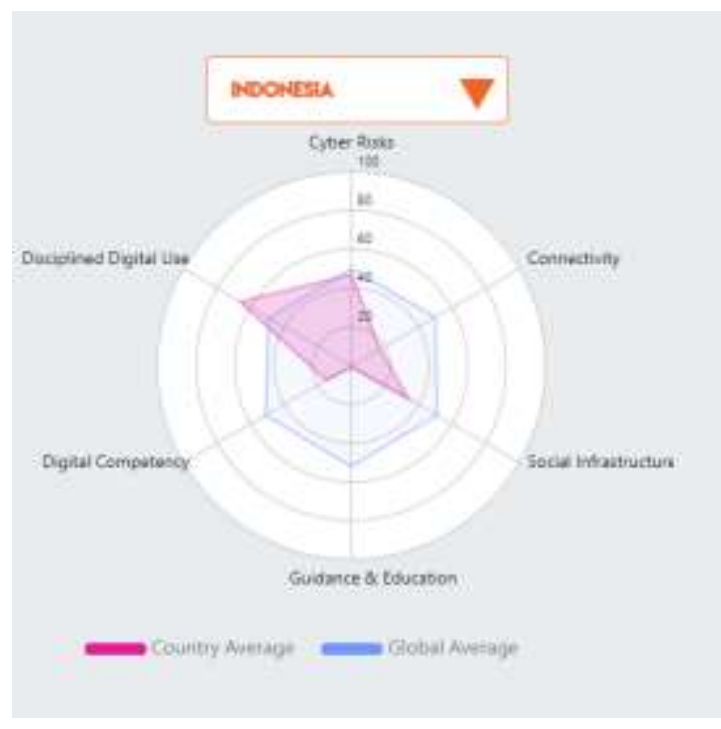

Gambar 1. COSI Indonesia by DQ Insitute

Berdasarkan data Child Online Safety Index (COSI) DQ Institute tahun 2020, seperti pada gambar 1, Indonesia menempati peringkat ke 26 dari 30 negara dengan nilai 17.5. Hal ini menempatkan Indonesia dengan performa jauh dibawah rata-rata terkait dengan keamanan online bagi anak-anak. Indonesia juga menempati posisi terendah, di peringkat ke 30 terkait pemberian bimbingan dan edukasi mengenai keamanan online. DQ Institute sebagai lembaga yang mewadahi COSI menyebutkan bahwa orang tua dan sekolah (dalam hal ini tenaga pendidik) perlu untuk diberdayakan dalam membantu dan membimbing anak-anak menuju dunia digital (DQ Institute, 2020). 


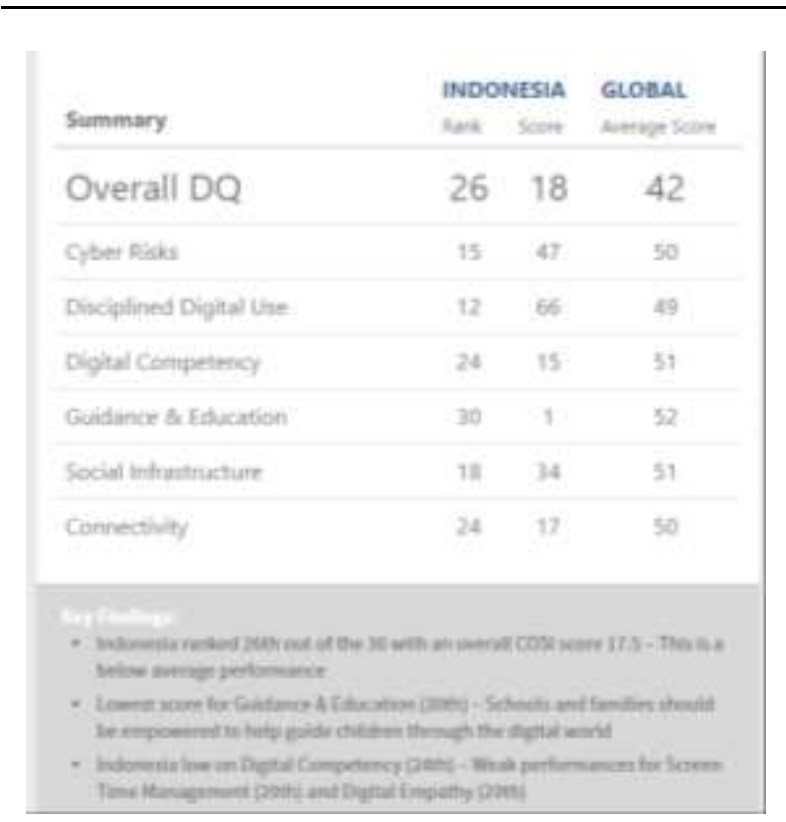

Gambar 2. Key findings by DQ Insitute

Bimbingan dan edukasi dalam data yang diukur COSI ini memberikan gambaran mengenai edukasi terkait E-Safety yang diberikan oleh pihak educator di Indonesia pada tahun 2020. Dalam data tersebut dua indikator yang digunakan mengukur frekuensi pemberian edukasi $E$-Safety dan persentase dari pengalaman anak terkait edukasi mengenai $E$-Safety di Indonesia adalah nol, atau tidak ditemukannya indikasi mengenai pelaksanaan bimbingan dan edukasi E-Safety melalui survey yang diadakan. Hal ini juga yang menempatkan Indonesia di posisi terbawah dari 30 negara yang diukur seperti pada gambar 2 yang memberikan gambaran mengenai kondisi Indonesia dalam pemetaan COSI.

Sangat rendahnya pengarahan dan edukasi dalam E-Safety di Indonesia membawa kita pada posisi yang sangat mengkuatirkan dan perlu menjadi perhatian khususnya dari pemerintah sebagai pembuat kebijakan dan para pendidik sebagai pihak yang berperan secara langsung dalam berinteraksi dengan anak didik.

Melihat urgensi dan keadaan yang ada saat ini, kami melihat pentingnya pelatihan E-Safety khususnya bagi para tenaga pendidik guna memperlengkapi mereka untuk membantu mempersiapkan dan melindungi anak dari berbagai kemungkinan dalam interaksi mereka di dunia maya terutama pada saat ini ketika terjadi perubahan dari pembelajaran tatap muka menjadi pembelajaran daring.

Ardiyansyah et al (2021) menyebutkan bahwa sebagai salah satu area kompetensi dari literasi digital, digital safety perlu untuk mendapatkan perhatian lebih mengingat perkembangan teknologi digital yang semakin pesat juga diiringi dengan munculnya berbagai ancaman yang ada di dunia maya. Upaya ini juga dalam memperlengkapi para pendidik sehingga diharapkan para guru dapat terus meningkatkan kemampuan literasi digitalnya secara umum dan khususnya yang berkaitan dengan digital Safety.

Sosialisasi Digital safety sendiri sejalan dengan program Pemerintah Republik Indonesia melalui Kementerian Komunikasi dan Informatika (Kominfo) dengan mendukung Gerakan Nasional Literasi Digital (GNLD) dan pemanfaatan teknologi khususnya untuk mengakselerasi transformasi pendidikan. Gerakan ini merupakan salah satu upaya Pemerintah untuk mengajak masyarakat dalam berbagi kreativitas lewat konten yang positif serta bijak dan bertanggung jawab dalam memanfaatkan internet (Kominfo, 2017). Menteri Pendidikan, Nadiem Makarim, juga menjelaskan bahwa transformasi pendidikan lewat pemanfaatan teknologi sangat membantu masyarakat ketika pembelajaran tatap muka tidak mungkin dilaksanakan, dengan catatan teknologi digunakan dengan cakap dan tepat sasaran (Detik, 2021).

Mitra pendidik yang mendaftar untuk mengikuti seminar dan workshop ini berasal dari latar belakang pendidik sebagai guru dari TK sampai SMA, pengurus yayasan pendidikan, PGRI (Persatuan Guru Republik Indonesia), dan juga aktivis gereja.

\section{METODE}

Pembatasan Sosial Berskala Besar (PSBB) yang berlangsung di Indonesia dari awal pandemi hingga pada saat pelaksanaan membatasi penyelenggaraan secara tatap muka, sehingga kegiatan ini dilaksanakan secara daring dengan 
memanfaatkan platform Zoom Meeting. Penggunaan platform ini juga memungkinkan kami untuk menjangkau peserta yang berada diberbagai daerah (Jabodetabek, Banjarmasin, Yogyakarta, Purworejo, Pekalongan, Wonosobo, Malang, Manado, dan Ambon), dimana mereka dapat mengikuti kegiatan ini karena dapat diakses dengan ketersediaan jaringan internet.

Pelaksanaan kegiatan Pengabdian Kepada Masyarakat \#NgajarDariRumah2.0 diselenggarakan dalam bentuk webinar dan workshop selama 5 hari, dimulai sejak tanggal 9 November 2020 hingga 13 November 2020. Sub tema E-Safety 101: Keamanan di Dunia Maya Bagi Pendidik dan Anak Didik berlangsung pada tanggal 10 November 2020 dan berlangsung pada waktu 09.00-12.00 WIB.

Pelaksanaan PkM dari persiapan hingga penyelenggaraan, menggunakan metode yang telah diterapkan sebelumnya dari \#NgajarDariRumah, yaitu ADDIE yang dibagi dalam lima tahapan: (1) Analyze, (2) Design, (3) Development, (4) Implementation, (5) Evaluation (Stefany \& Purbojo, 2021).

Tahapan analyze dilakukan secara bersamaan dengan tim \#NgajarDariRumah2.0 dengan mendata profil audiens dan pengumpulan data dari para pendidik yang mendaftar pada webinar E-Safety. Tahapan design dan development dilakukan dengan menyesuaikan profil dan kebutuhan dari para pendidik terkait dengan sosialisasi E-Safety. Untuk Implementation yang dilakukan pada hari penyelenggaraan, pelaksanaan dilakukan melalui pertemuan secara online. Setelah tahapan penyelenggaraan, dilakukan evaluation untuk mengetahui respon atas penyelenggaraan webinar ESafety101: Keamanan di Dunia Maya Bagi Pendidik dan Anak Didik

Pelaksanaan kegiatan webinar PKM ini dihadiri oleh 50 peserta akun Zoom dengan 57 peserta yang hadir, terdiri dari pendidik dan berbagai institusi terkait, mencakup PAUD, SD, SMP hingga SMA. Jumlah peserta akun zoom tidak mewakili keseluruhan jumlah peserta, dikarenakan beberapa akun zoom yang digunakan diakses oleh lebih dari satu peserta. salah satunya Yayasan Pendidikan Satyawiguna di Pekalongan yang menggunakan satu akun Zoom yang diproyeksikan dengan projector sehingga semua peserta dari yayasan mereka dapat mengikuti webinar tersebut secara bersama-sama.

Metode yang digunakan pada saat tahapan implementasi dalam menyampaikan sosialisasi mengenai E-Safety bagi tenaga pendidik adalah dengan metode ceramah, tanya jawab yang dikombinasikan dengan demonstrasi, dan praktik penggunaan akses bahan ajar E-Safety yang juga disertai diskusi.

Pelaksanaan yang dilakukan adalah sebagai berikut: 1) Ceramah, digunakan untuk menyampaikan materi secara teoritis mengenai $E$ Safety; 2) Tanya Jawab, digunakan untuk melakukan diskusi dengan peserta sehingga pemateri dapat memberikan pemahaman yang lebih dalam terkait pertanyaan yang diajukan; 3) Demonstrasi dan praktik, digunakan untuk memberikan latihan secara langsung dimana peserta dapat mengakses materi bahan ajar untuk peserta didik, sehingga peserta tidak hanya dibekali secara teoritis tetapi juga memahami bagaimana cara mempraktekkannya $E$-Safety untuk kegiatan belajar mengajar secara daring; dan 4) Diskusi, digunakan untuk menambah pemahaman peserta terkait proses praktik yang baru saja diikuti dan juga menjawab berbagai pertanyaan yang muncul mengenai ESafety.

\section{HASIL DAN PEMBAHASAN}

Sosialisasi dan pembahasan mengenai E-Safety mencakup: 1) Literasi digital: E-Safety, 2) Cyber crime, 3) Peran edukator, dan 4) Sumber pembuatan bahan ajar E-Safety. Penyampaian materi dilaksanakan dengan ceramah disertai dengan praktik demonstrasi serta eksplorasi penggunaan materi E-Safety yang dapat diakses.

\section{Literasi Digital: $E$-Safety}

Literasi digital mengenai E-Safety dimulai dengan pemaparan data dan fakta mengenai kondisi dan situasi yang ada saat ini. Interaksi dengan perangkat digital yang meningkat secara 
eksponensial menuntut adanya literasi digital secara tepat dan penerapan E-Safety sebagai upaya perlindungan terhadap anak dan remaja peserta didik.

Pengetahuan akan bahaya dan resiko dunia maya dapat disosialisasikan oleh pendidik kepada anak didik dengan cara yang tepat, dimana materi dapat disesuaikan dengan tingkat usia anak dan mengakomodasikan nilai-nilai penting yang perlu mereka pahami dalam konteks berinteraksi secara online. Seperti pada gambar 3, kata kunci (SMART) dan poster yang menjelaskan bagaimana melindungi anak didik ketika mereka mengakses dunia digital.

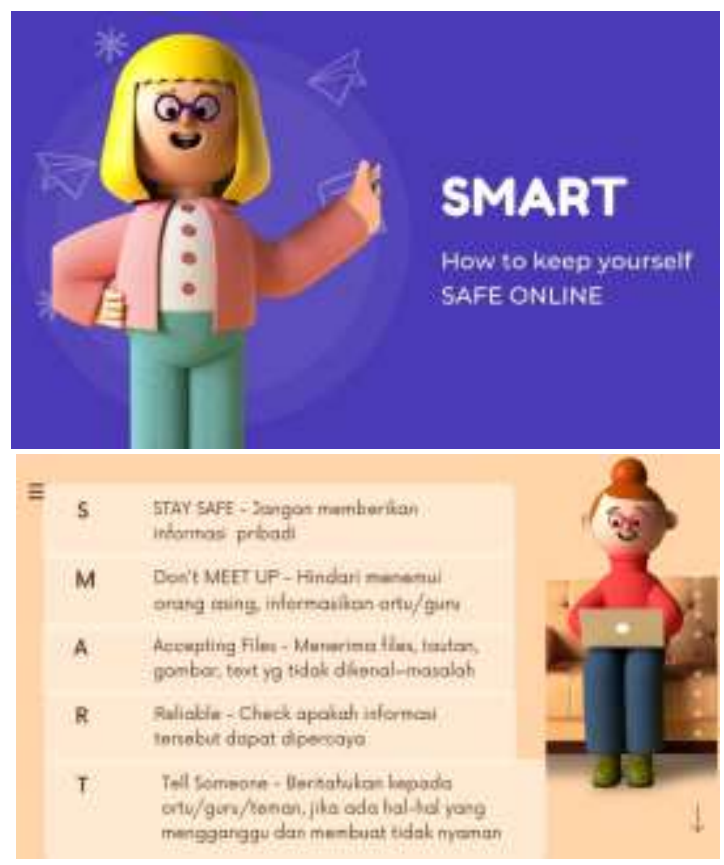

Gambar 3. SMART

\section{Cyber Crime}

Resiko terkait keamanan di dunia maya terkait cyber crime atau kejahatan digital perlu diwaspadai dan diantisipasi secara dini. Penjelasan dari data terkait eksploitasi seksual anak online (ESA), grooming, sexting, pemerasan seksual dan juga live streaming untuk kekerasan seksual pada anak, disampaikan berdasarkan kondisi saat pelaksanaan. Data yang diterima NCMEC (National Center for Missing and Exploited Children) mencatat terdapat
2,2 juta kasus eksploitasi seksual anak online dan meningkat tajam menjadi 4,2 juta kasus per April 2020 pada masa pandemi dimulai. Dari 82\% kejahatan seksual online, pelaku menggunakan media sosial korban untuk mengumpulkan informasi.

Cyber bullying atau perundungan secara online juga merupakan kejahatan digital yang kerap dialami baik oleh anak, remaja maupun orang dewasa. Perundungan di dunia maya juga memiliki persentase kasus yang cukup tinggi. Data dari UNICEF (2020), mengungkapkan bahwa $42 \%$ pengguna teknologi digital pernah mengalami perundungan, serta $25 \%$ remaja pernah mengalaminy cyber bullying secara berulang.

Pemahaman akan kejahatan digital diharapkan dapat memberikan wawasan dan tindakan untuk pencegahan agar hal tersebut tidak dialami oleh anak didik atau setidaknya dapat ditangani dengan tepat ketika sudah terjadi. Pencegahan lebih baik diberikan untuk menghindari dampak yang merugikan bagi peserta didik.

\section{Peran Edukator}

Peran edukator menjadi salah satu kunci utama dalam memberikan bimbingan dan edukasi terkait E-Safety. Empat peranan yang dimiliki oleh educator adalah sebagai: 1) Learner, pendidik memiliki pengetahuan dan memahami terkait $E$ Safety; 2) Advisor, pendidik menjadi pihak yang dituju ketika peserta didik menghadapi permasalahan terkait E-Safety; 3) Teacher, pendidik dapat menyampaikan materi dan pelaksanaan $E$ Safety dengan efektif ; dan 4) An Identifier, pendidik memantau dan mengamati perubahan dalam perilaku peserta didik terkait E-Safety dan resikonya.

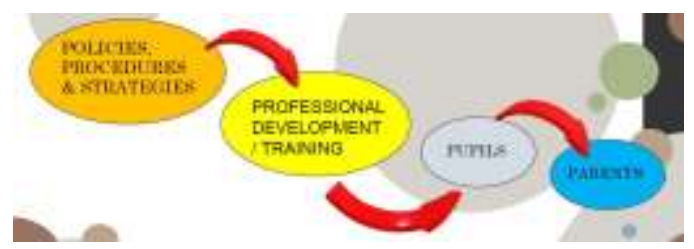

Gambar 4. Improving E-Safety from Shipton (2011) 
Peranan sekolah dalam sosialisasi dan implementasi pelaksanaan E-Safety dapat dilakukakn dengan menerapkan prosedur yang diadopsi dari Shipton (2011) Procedure for improving E-Safety in Primary Schools. Prosedur ini terdiri dari: 1) Policies, procedures \& strategies, 2) Professional Development/Training, 3) Pupils, dan 4) Parents. Peran dari pelaksanaan webinar $E$ Safety 101: Keamanan di Dunia Maya Bagi Pendidik dan Anak Didik dapat menjadi bagian dari Professional Development/Training guna memperlengkapi peranan pendidik.

\section{Bahan Ajar}

Dalam memperlengkapi peranan pendidik terkait E-Safety, diberikan materi dan bahan ajar menjadi sumber yang dapat digunakan untuk mensosialisasikan E-Safety. Sumber pembuatan bahan ajar didapatkan dari berbagai akses yang telah ada; 1) Be Internet Awesome Curriculum from Google (gambar 5), 2) InCtrl digital citizenship website (gambar 6), dan 3) Common Sense Education (gambar 7).

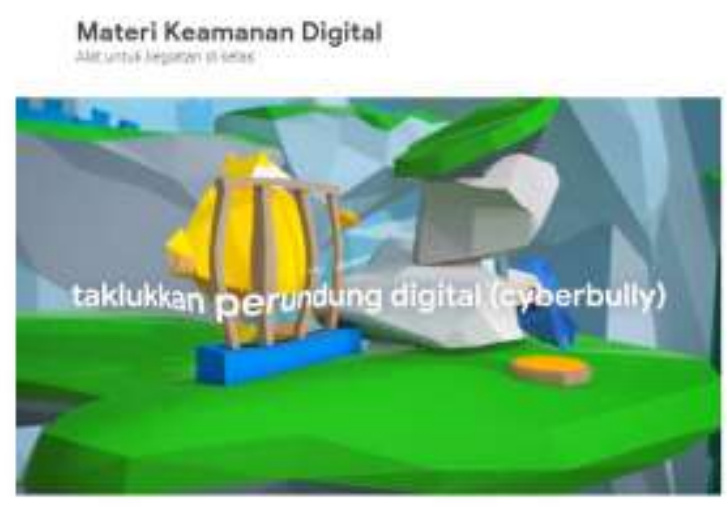

Gambar 5. Be Internet Awesome from Google

Untuk bahan ajar yang diberikan, terdapat berbagai referensi yang berbeda dengan tinjauan usia anak dan juga aktifitas yang dapat dilakukan berdasarkan.

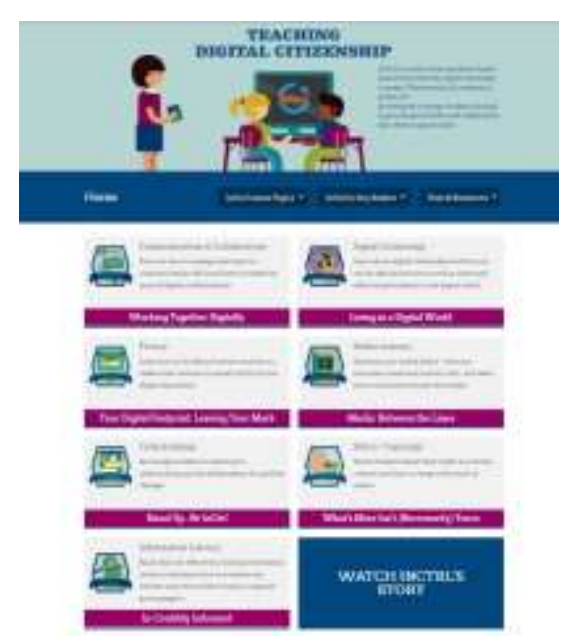

Gambar 6. Teaching Digital Citizenship from InCtrl

Penggunaan dan akses ini didemonstrasikan secara langsung kepada peserta secara live (on hand dan akses link) dan pada saat yang bersamaan sehingga mereka dapat langsung mempraktikkan dan mengakses semua sumber materi yang ada.

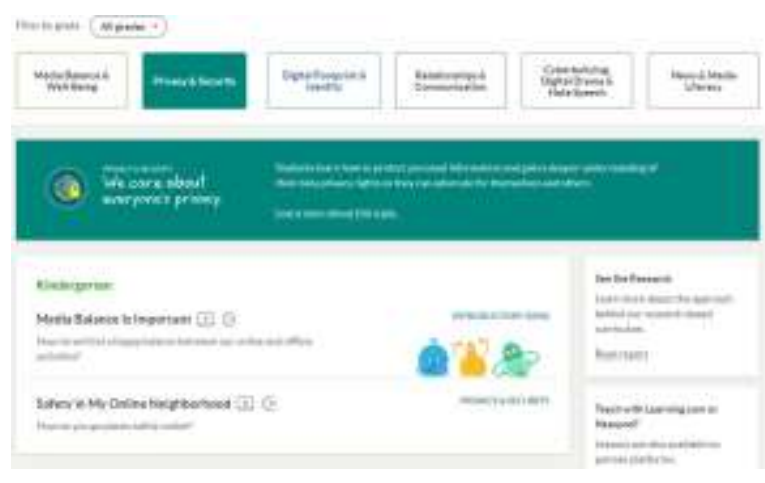

Gambar 7. Digital Citizenship Curriculum from Common Sense Education

Berbagai permasalahan terkait E-Safety dibahas dalam sesi tanya jawab dan diskusi. Berbagai temuan dan kendala yang dihadapi oleh para pendidik yang diangkat mencakup keterbatasan pengetahuan, materi, hingga kasus yang dihadapi di lapangan. Salah satu kendala mensosialisasikan $E$ Safety ini dikarenakan program ini tidak ada dalam kurikulum pengajaran sehingga pendidik 
mengalami kendala. Terbatasnya pengetahuan terkait E-Safety juga dikarenakan belum pernah adanya training maupun sosialisasi terkait E-Safety.

Sebagai pendidik, kendala lainnya adalah menemukan bagaimana mereka dapat ikut andil dalam ikut mengawasi dan mengontrol penggunaan dan akses ke dunia digital tersebut. Penekanan mengenai bagaimana pentingnya untuk dapat menjadikan akses ke dunia digital tersebut sebagai suatu kesempatan untuk belajar, menjelajah dan berkembang menjadi salah satu hal yang sangat krusial. Mempelajari mengenai keamanan di dunia maya bukan berarti menghentikan atau membatasi akses secara berlebihan, tetapi untuk menjadi pengguna dan warga dunia digital yang tanggap dan cerdas, bukan melarang, tetapi memperlengkapi dan mendampingi, dengan membangun kesadaran mengenai E-Safety.

Berbagai kasus aktual yang terjadi pada anak didik dijadikan sebagai contoh kasus yang ada. Kejadian aktual yang dialami, termasuk kasus sexting, bullying, dan kecanduan game online. Pertanyaan mengenai berbagai konsekuensi dari penggunaan akses internet, seperti kecanduan akan game online dan cara penanganannya ditekankan dengan melibatkan pihak terkait dan tenaga konselor professional yang memang mempunyai kemampuan dalam mengatasi masalah tersebut. Pendidik dan orang tua menjadi pihak yang perlu menyadari akan adanya gejala awal tersebut.

Akses untuk materi, terutama materi berbahasa Indonesia menjadi permintaan oleh pendidik sebagai referensi, terutama untuk mereka yang berada di daerah. Sumber referensi dapat menjadi acuan dalam memulai sosialisasi pentingnya mengimplementasikan E-Safety untuk anak didik. Pendidik menyadari rendahnya awareness akan pentingnya sosialisasi mengenai E-Safety.

Beralihnya pembelajaran menjadi online dan tuntutan untuk melakukan berbagai aktifitas di dunia digital, merupakan hal yang relatif baru, sehingga kesiapan menghadapi ekspos dari dunia digital juga belum terbangun dengan baik. Ketidakpahaman akan pentingnya E-Safety ini sendiri juga menjadi hal yang perlu dicermati dalam meningkatkan kesadaran untuk sosialisasi E-Safety.
Evaluasi dari pelaksanaan webinar E-Safety 101: Keamanan di Dunia Maya Bagi Pendidik dan Anak Didik, dilakukan dengan survey singkat kepada peserta terkait pelaksanaan webinar. Hasil survey ini antara lain adalah : 37\% menyatakan sangat setuju dan $63 \%$ menyatakan setuju bahwa materi yang disampaikan relevan dengan peran mereka sebagai tenaga pendidik. Sedangkan untuk pertanyaan survey mengenai apakah materi ini baru diketahui setelah mengikuti webinar ini; $11 \%$ menjawab sangat setuju, $60 \%$ menjawab setuju, dan $29 \%$ menjawab tidak setuju. Terdapat $71 \%$ peserta yang mendapati bahwa materi E-Safety ini adalah hal yang baru untuk mereka.

Setelah mengikuti kegiatan ini, pendidik lebih memahami pentingnya $E$-Safety dalam setiap proses pembelajaran secara daring. Diharapkan dengan relevansi yang ada dan juga kebaharuan materi yang diberikan, sosialisasi literasi digital E-Safety dapat dilaksanakan dengan lebih baik bagi peserta didik dalam mendukung resiliensi anak didik ketika berinteraksi di dunia digital.

\section{KESIMPULAN}

Edukasi dan sosialisasi mengenai E-Safety menjadi salah satu hal yang perlu menjadi perhatian para pendidik di Indonesia. Pelaksanaan webinar ESafety 101: Keamanan di Dunia Maya Bagi Pendidik dan Anak Didik menjadi salah satu bagian dari literasi digital dengan fokus untuk meningkatkan awareness akan pentingnya melindungi anak dan generasi muda dengan edukasi yang tepat terkait akses di dunia digital

Untuk mempersiapkan anak didik yang mempunyai resiliensi ketika berinteraksi di dunia digital, dukungan dari pendidik menjadi salah satu kunci utama. Memperlengkapi pendidik untuk dapat berperan secara maksimal dalam mempersiapkan anak dan generasi muda diawali dengan kesiapan pendidik. PkM E-Safety 101: Keamanan di Dunia Maya Bagi Pendidik dan Anak Didik diharapkan dapat mendukung peran pendidik dalam sosialisasi literasi digital terkait E-Safety dan memberikan solusi akan keterbatasan materi bahan ajar yang dapat digunakan. 
Sosialisasi mengenai E-Safety juga diharapkan dapat menjadi suatu pembekalan yang akan membantu mempersiapkan anak didik dan melindungi mereka dari berbagai kemungkinan menjadi korban dari pengaruh buruk internet maupun kejahatan di dunia maya.

Output yang diharapkan dapat dilakukan oleh para pendidik adalah sosialisasi edukasi E-Safety sebagai langkah awal literasi digital kepada anak didik. Baik pendidik maupun peserta didik dapat memaksimalkan segala potensi yang dapat diperoleh dari akses di dunia maya namun juga memiliki kewaspadaan dan kesadaran mengenai keamanannya.

Penggunaan dan akses materi yang telah diberikan diharapkan dapat menjadi acuan untuk memulai dan memperlengkapi edukasi terkait keamanan di dunia maya bagi pendidik dan anak didik mereka.

\section{UCAPAN TERIMAKASIH}

Terima kasih kepada Fakultas Ilmu Sosial dan Ilmu Politik (FISIP) UPH yang sudah mendukung rangkaian kegiatan Webinar \#NgajarDariRumah2.0. Terima kasih juga untuk teman-teman dosen, tutor dan staff di Program Studi PJJ Ilmu Komunikasi atas kerja samanya selama 5 hari pelaksanaan Webinar \#NgajarDariRumah2.0. Tidak ketinggalan juga Bapak dan Ibu tenaga pendidik di seluruh Indonesia baik yang mengikuti kegiatan ini melalui platform Zoom Meeting ataupun live streaming di Youtube. Semoga materi yang disampaikan dapat memperlengkapi dan menunjang pembelajaran daring dan juga menambah referensi terkait literasi digital, terutama untuk resiliensi anak didik ketika berinteraksi di dunia maya.

\section{REFERENSI}

Aly, M. N., Rizma Outri, A. N., Rosyida, G., Hamidah, A., Ahmad, A. S., Suryani, H. A., ... Ilmi, I. Q. (2020). Panduan Aman "New Normal" Menghadapi Pandemi Covid-19.
Jurnal Layanan Masyarakat (Journal of Public Services), 4(2), 415. https://doi.org/10.20473/jlm.v4i2.2020.415422

Briandana, R., \& Dwityas, N. A. (2019). Media Literacy: An Analysis of Social Media Usage among Millennials. International Journal of English Literature and Social Sciences, 4(2), 488-496. https://doi.org/10.22161/ijels.4.2.44

Bubb, S., \& Jones, M. A. (2020). Learning from the COVID-19 home-schooling experience: Listening to pupils, parents/carers and teachers. Improving Schools, 23(3), 209-222. https://doi.org/10.1177/1365480220958797

C. Whittle, H., Hamilton-Giachritsis, C., \& R. Beech, A. (2013). Victims' Voices: The Impact of Online Grooming and Sexual Abuse. Universal Journal of Psychology, 1(2), 59-71.

https://doi.org/10.13189/ujp.2013.010206

Common Sense Org. (n.d.). Digital Citizenship Curriculum. Diambil dari https://www.commonsense.org/education/digit al-citizenship/curriculum?topic=privacy-security

DQ Institute. (2020). 2020 COSI Report.

Fernandes, B., Biswas, U. N., Tan-Mansukhani, R., Vallejo, A., \& Essau, C. A. (2020). The impact of COVID-19 lockdown on internet use and escapism in adolescents. Revista de Psicologia Clinica con Ninos y Adolescentes, 7(3), $59-65$. https://doi.org/10.21134/rpcna.2020.mon.2056

Findings, K., \& Perceptions, V. (n.d.). UKCCIS RH63 Impact of Online Grooming and Abuse.

InCtrl Org. (n.d.). Teaching Digital Citizenship. Diambil dari https://teachinctrl.org/

Internetmatters.Org. (2019). Vulnerable Children in a Digital World 2019 - Research Summary and Insights, 1-3.

Jessie, R., \& Thinkuknow, A. (2020). Sharing Pictures Quiz My Name is, (3), 4-5.

Katz, A., \& El Asam, A. (2018). Vulnerable Children in a Digital World. Kelsi.Org.Uk. Diambil dari www.thecybersurvey.co.uk.

Kurnianingsih, I., Rosini, R., \& Ismayati, N. (2017). Upaya Peningkatan Kemampuan Literasi Digital Bagi Tenaga Perpustakaan Sekolah 
dan Guru di Wilayah Jakarta Pusat Melalui Pelatihan Literasi Informasi. Jurnal Pengabdian kepada Masyarakat (Indonesian Journal of Community Engagement), 3(1), 61. https://doi.org/10.22146/jpkm.25370

Limilia, P., \& Aristi, N. (2019). Literasi Media dan Digital di Indonesia: Sebuah Tinjauan Sistematis. Jurnal Komunikatif, 8(2), 205222. https://doi.org/10.33508/jk.v8i2.2199

Sharples, M., Graber, R., Harrison, C., \& Logan, K. (2008). E-safety and Web 2.0, (September), 138.

Stefany, S., Purbojo, R., \& Adeline, C. (2020). Digital Literacy: Online Class Managerial for Educators. Jurnal Sinergitas PKM \& CSR, 4(3), 215. https://doi.org/10.19166/jspc.v4i3.2805

Sudrajat, J. (2020). Kompetensi Guru Di Masa Pandemi Covid-19. Jurnal Riset Ekonomi dan Bisnis, 13(2), 100. https://doi.org/10.26623/jreb.v13i2.2434

Suwarto, D. H. (2018). Gerakan Literasi Media Indonesia.

UNICEF, Foundation, W. C., Organization, G. A. and W. H. (2020). COVID-19 and its implications for protecting children online, (April), 1-6. Diambil dari https://www.endviolence.org/sites/default/files/2020-

07/COVID-19 and its implications for protecting children online_Final \%28003\%29_0.pdf 